\title{
Young cells
}
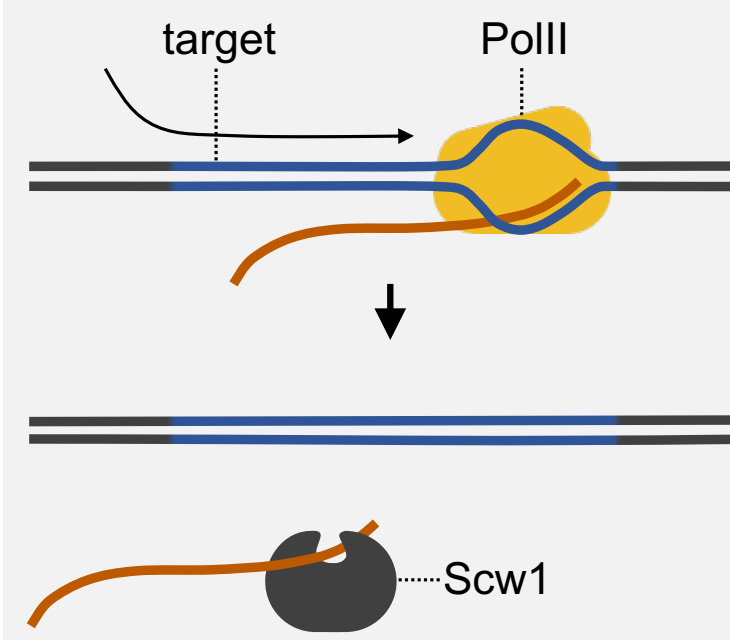

Old cells

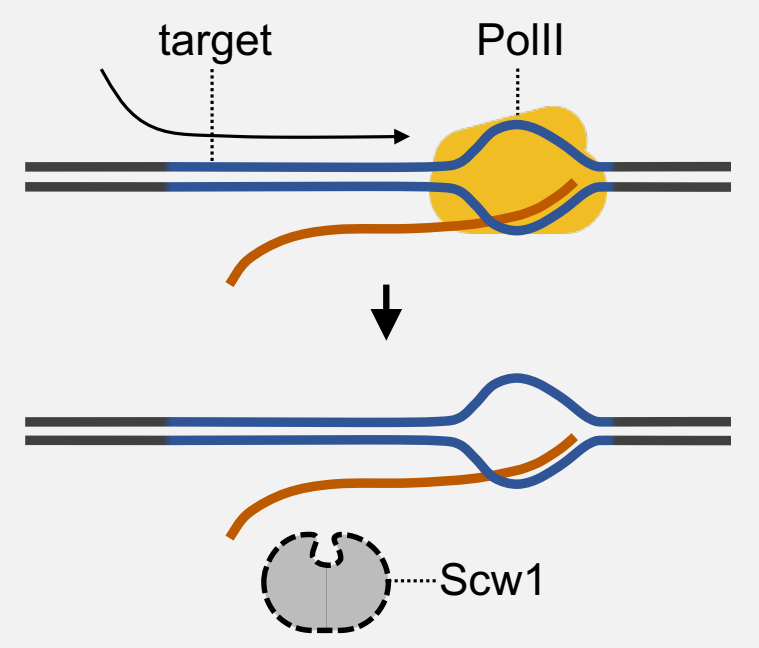

S10 Fig. Model for how Scw1 levels might affect genome rearrangement at its targets. In young cells, Scw1 is present and binds its targets at their 3' UTRs. In old cells, Scw1 is absent and thus leaves nascent RNA of its targets free to anneal with template ssDNA. 